\title{
New and Noteworthy
}

\section{Mastering America}

Southern Slaveholders and the Crisis of American Nationhood Robert E. Bonner

\$80.00: Hardback: 978-0-521-83395-0: 310 pp.

\$21.99: Paperback: 978-0-521-54177-0

\section{Political Moderation in America's First Two Centuries \\ Robert McCluer Calhoon \\ \$90.00: Hardback: 978-0-521-51554-2: 310 pp. \\ \$24.99: Paperback: 978-0-521-73416-5}

The American 1930s

A Literary History

\section{Peter Conn}

\$90.00: Hardback: 978-0-521-51640-2: 280 pp. \$29.99: Paperback: 978-0-521-73431-8

\section{The Cambridge Companion to Bob Dylan}

Edited by Kevin J. H. Dettmar

Cambridge Companions to American Studies

\$90.00: Hardback: 978-0-521-88694-9: 200 pp.

\$24.99: Paperback: 978-0-521-71494-5

\section{The Cambridge Introduction to Robert Frost}

Robert Faggen

Cambridge Introductions to Literature

\$70.00: Hardback: 978-0-521-85411-5: 200 pp.

\$19.99: Paperback: 978-0-521-67006-7

\section{The Cambridge Introduction to} Edgar Allan Poe

Benjamin F. Fisher

Cambridge Introductions to Literature

\$60.00: Hardback: 978-0-521-85967-7: 146 pp.

\$19.99: Paperback: 978-0-521-67691-5

\section{Where Have All the Liberals Gone?}

Race, Class, and Ideals in America

James R. Flynn

\$28.00: Hardback: 978-0-521-49431-1: 352 pp.

\section{The G.I. Bill}

Kathleen Jill Frydl
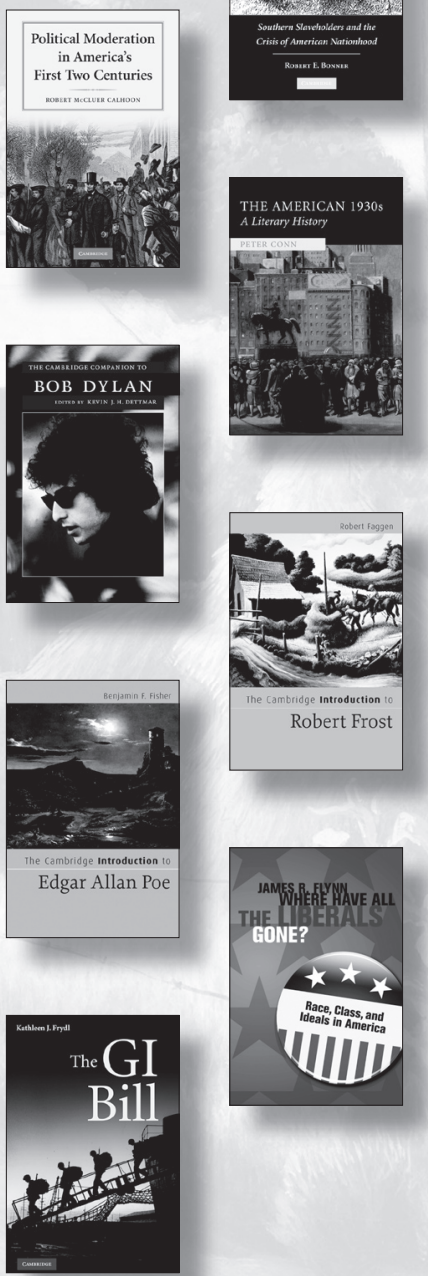
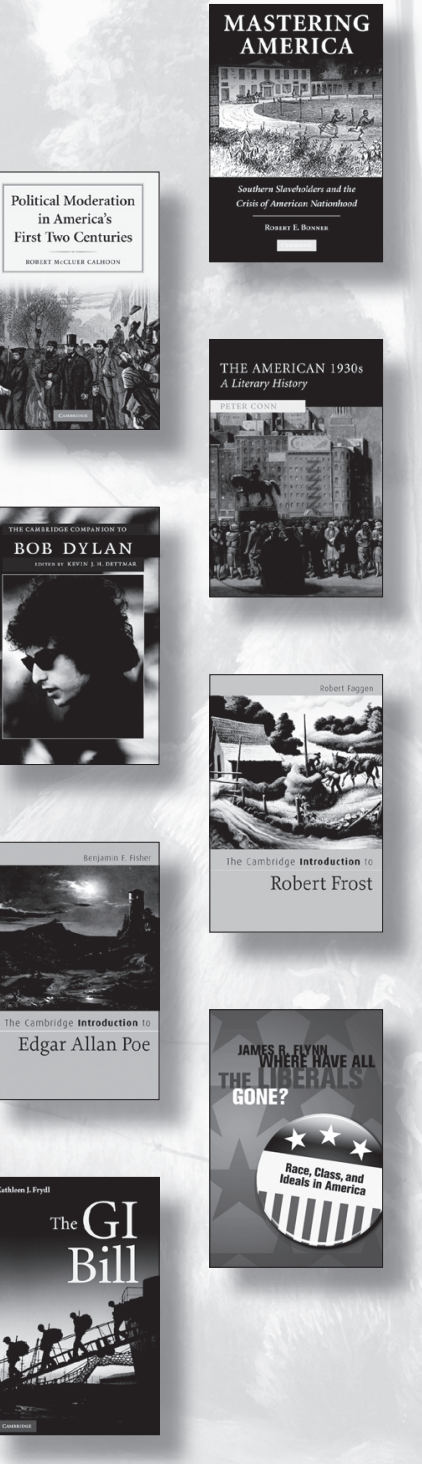

Prices subject to change. 


\section{New and Noteworthy}

The Cambridge Introduction to Sylvia Plath Jo Gill

Cambridge Introductions to Literature

\$70.00: Hardback: 978-0-521-86726-9: 168 pp.

\$19.99: Paperback: 978-0-521-68695-2

\section{Military Education and the Emerging} Middle Class in the Old South Jennifer R. Green

\$80.00: Hardback: 978-0-521-89493-7: 314 pp.

\section{All the Way with LBJ}

The 1964 Presidential Election

Robert David Johnson

\$80.00: Hardback: 978-0-521-42595-7: 328 pp.

\$22.99: Paperback: 978-0-521-73752-4

\section{The Cambridge Introduction to}

Zora Neale Hurston

Lovalerie King

Cambridge Introductions to Literature

\$70.00: Hardback: 978-0-521-85457-3: 160 pp.

\$19.99: Paperback: 978-0-521-67095-1

\section{Creating Abundance}

Biological Innovation and American Agricultural Development

Alan L. Olmstead and Paul W. Rhode

\$80.00: Hardback: 978-0-521-85711-6: $480 \mathrm{pp}$.

\$23.99: Paperback: 978-0-521-67387-7

Nixon, Kissinger, and U.S. Foreign

Policy Making

The Machinery of Crisis

Asaf Siniver

\$80.00: Hardback: 978-0-521-89762-4: 270 pp.

Now in Paperback...

Transatlantic Encounters

American Indians in Britain, 1500-1776

Alden T. Vaughan

\$24.99: Paperback: 978-0-521-73817-0: 364 pp.
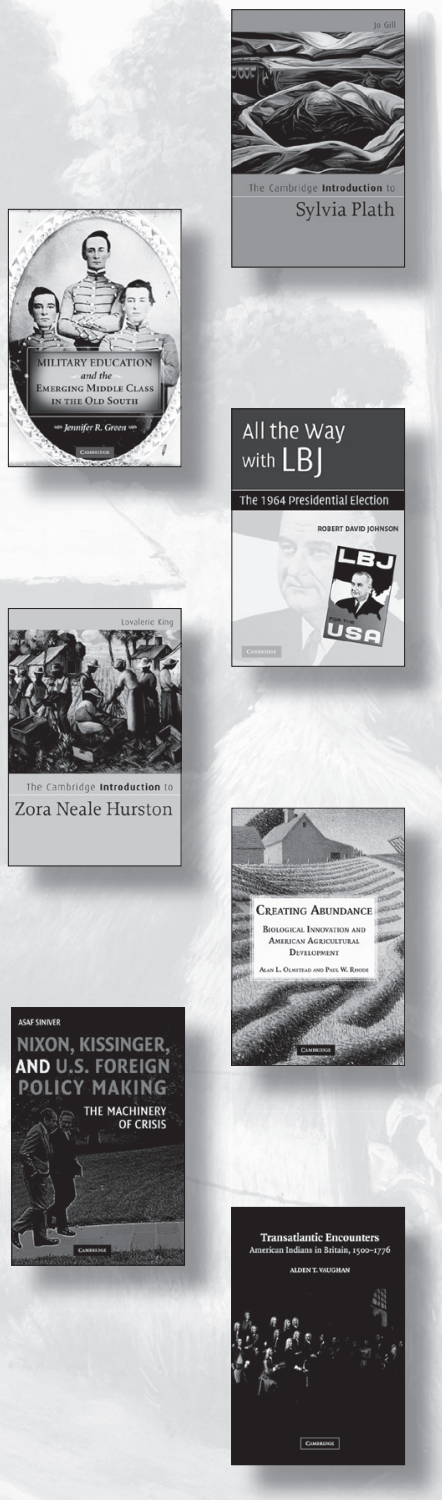


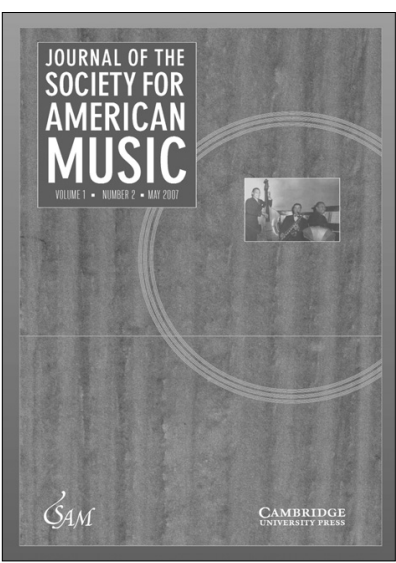

Journal of the Society for American Music

is available online at

journals.cambridge.org/sam

To subscribe contact

Customer Services

\section{in Cambridge:}

Phone +44 (0)1223 326070

Fax +44(0)1223 325150

Email journals@cambridge.org

\section{in New York:}

Phone (845) 3537500

Fax (845) 3534141

Email

subscriptions_newyork@cambridge.org

\section{Journal of the}

Society for

\section{American}

\section{Music}

Published on behalf of the Society for American Music

\section{Editors}

Ellie M. Hisama, Columbia University, New York, USA

Journal of the Society for American Music (JSAM) is an international, peer-reviewed journal dealing with all aspects of American music and music in the Americas. JSAM is dedicated to supporting scholarship that transcends disciplinary boundaries, cutting across historical musicology, music theory, ethnomusicology, cultural theory, identity studies, and American studies. JSAM encourages international dialogue across disciplines. The journal features articles, reviews of books, recordings, and multimedia items, and explorations of special topics.

Price information is available at journals.cambridge.org/sam

\section{Free email alerts} Keep up-to-date with new material sign up at journals.cambridge.org/register

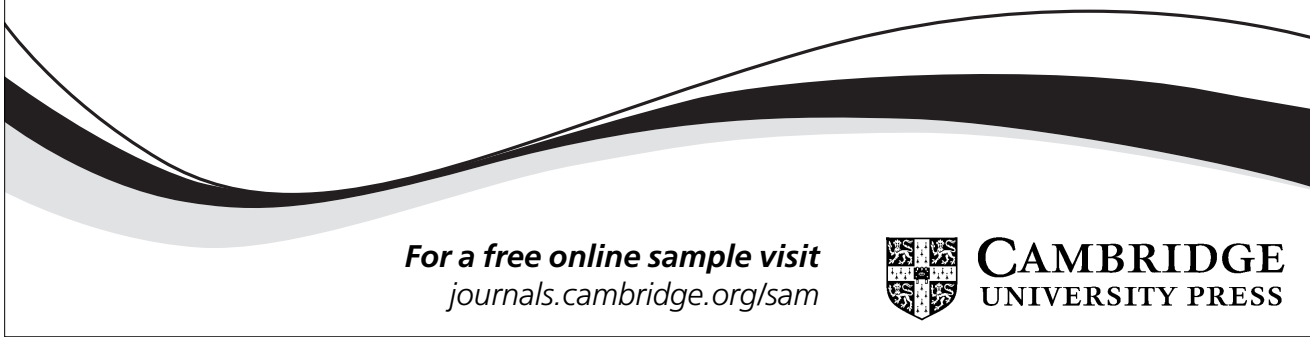




\section{Editorial policy}

Journal of American Studies publishes works by scholars from all over the world on American literature, history, institutions, politics, economics, film, popular culture, geography and related subjects.

A 'Notes and Comments' section provides a forum for shorter pieces and responses from readers to points made in articles or reviews.

\section{Submissions}

All contributions and editorial correspondence should be sent to: Susan Castillo, Department of American Studies, King's College London, Strand, London WC2R 2LS. The Editor can also be contacted via email at Susan.Castillo@kcl.ac.uk.

Submission of an article is taken to imply that it has not previously been published, and has not been submitted for publication elsewhere. Authors of articles published in the journal assign copyright to Cambridge University Press (with certain rights reserved) and will receive a copyright assignment form for signature on acceptance of your paper.

Contributors are responsible for obtaining permission to reproduce any material in which they do not own copyright, to be used in both print and electronic media, and for ensuring that the appropriate acknowledgements are included in their manuscript.

\section{Manuscript preparation}

Articles should not exceed 6,000 words.

Manuscripts should be submitted as an electronic attachment and as a paper copy. All submissions should be accompanied by an abstract of 150 words and a short $\mathrm{CV}$ of the author(s).

In the event of the manuscript being accepted for publication two final hard copies should be resubmitted with the final electronic file on disk or $\mathrm{CD}$. The author should provide a note of his or her institutional affiliation at the foot of the first page of the manuscript.

The author's email address should be clearly readable on the first page of the typescript, in case the disk cannot be opened. Text files should be word documents if PC and $\mathrm{rtf}$ documents if Macintosh. File names should be of the type AMSauthorsurname.doc or .rtf for ease of identification.

Diagrams, maps, and illustrations can be submitted as hard copy but also as electronic files if available. Artwork of any kind should be made into and eps file or a tif file and the file name should be AMSauthorsurname1.eps or .tif (where the number is the figure number).

Contributors should keep one copy of the typescript for correcting proofs.

\section{Text preparation}

Spelling and punctuation may conform either to British or American usage, providing it is consistent throughout. In either case quotation should follow the style of the original.

Use-ize (as in organize), connection, enquiry, judgement, focussed, role; elite, regime (without accents), but communiqué.

Quotations: Long quotations (i.e., of 50 words or more) will be set apart in smaller type, without quotation marks. They should also be indicated on the typescript. Shorter quotations will be set in the text, with double quotations within quotations, use single inside double.

Punctuation: All commas and periods ending quotations should appear inside the quotation marks; other punctuation goes outside unless it is actually part of the matter quoted.

Ellipsis within a sentence should be indicated by three ... spaced periods. Ellipsis at the end of a sentence should be indicated by three spaced periods following the sentence period, i.e. four periods in all.

Indentation: The first line of articles and of sections within articles and of reviews should not be indented. All other paragraphs begin with indentation.

Dates: 13 January 1976 (but 13 Jan. in footnotes); March 1978; 1920s; 1965-68; 1904-08 (except in headings: 1771-1773); seventeenth century; always abbreviate months in footnotes.
Figures: Spell one to ninety-nine in text, except e.g. 75 voted for, 39 against, and 15 abstained. Spell only one to nine in footnotes. 15 percent (but use $\%$ in footnotes).

Abbreviations: Mr., Dr., Jr., Sr. (as in Richard Henry Dana, Sr.); but USA, USSR, UN, NATO, ACLS, DAB, PMLA (without periods). Ibid., et al., etc., loc. cit. (Latin with periods).

Tables: Use space rather than vertical rules, unless the latter are absolutely essential sources and notes should appear immediately below each table.

Footnotes should be used sparingly: in general, to give sources of direct quotations, references to main authorities on disputable questions, and evidence relied on for a new or unusual conclusion. They should be numbered consecutively.

Capitalization: southern, northern, southerner, northerner, governor, President of the United States, South, North, Midwest.

Citations should wherever possible be to authoritative editions rather than to paperback reprints of no textual authority.

Books should be cited as follows, complete with publisher's name:

W.R. Brock, American Crisis: Congress and Reconstruction 1865-1867(London: Macmillan, 1963), 274-83

H.C. Allen and C.P. Hill, eds., British Essays in American History (London: Edward Arnold, 1957)

Frances Anne Kemble, Journal of a Residence on a Georgia Plantation in 1838-1939, ed. John A. Scott (New York: Alfred A. Knopf, 1961), $260 f f$.

John Livingstone Lowes, The Road to Xanadu: A Study in the Ways of the Imagination 2nd edn. (1930; rept. New York: Alfred A. Knopf, 1959), 61.

Helen T. Catterall, ed., Judicial Cases Concerning American Slavery and the Negro, 5 vols. (Washington, DC: US Govt. Printing Office, 1926-37), 1, 216-21, 247; 4,16.19.

John M. Hill, An Introduction to American Fiction, 2nd edn. rev. (Princeton: Princeton University Press, 1976), xi-xiii.

Subsequent citations should be indicated thus:

Immediately following: Ibid., 47.

Within the next ten footnotes: Hill, 271-78

When the work has not been cited, in any form, for more than ten footnotes: Hill, American Fiction, 394

Avoid op. cit.

Journals should be cited as follows:

Bernard Poli, "The Hero in France and America," Journal of American Studies, 2 (1968), 225-38

Avoid Roman numerals. Indicate volume numbers by italicising, thus: 64 Vol. No. Ch. Pt. all cap.

Page numbers: 152-55, 113-257, 1365-69

Abbreviations to be italic, e.g. Reviews in North America Literature, hereafter abbreviated to $R N A L$.

Weekly magazines

"Who controls the Democratic Party?" Time, 19 Sept. 1975, 19-24

Newspapers

Norman Mailer, "Reflections on James Baldwin's 'Apocalypse", New York Times, 9 Oct. 1968,23 .

\section{Proofs}

Typographical or factual errors only may be changed at proof stage. The publisher reserves the right to charge authors for correction of nontypographical errors.

\section{Offprints}

Article authors will receive a PDF file of their work and a copy of the journal issue on publication. 


\section{American}

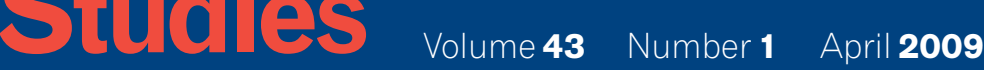

\section{ARTICLES}

1 José Martí's "Evening of Emerson" and the United Statesian Literary Tradition

LAURA LOMAS

19 Anatomy of a Scare: Yellow Peril Politics in America, 1980-1993 M. J. HEALE

49 Nabokov's Dystopia: Bend Sinister, America and Mass Culture WILL NORMAN

71 Language and Signs: An Interview with Ojibwe Novelist David Treuer PADRAIG KIRWAN

89 Reading the Historical Novel: Reworking the Past and the Relation of Blackfeet History in James Welch's Fools Crow SARAH MARTIN

101 McGuffey's Oxford (Ohio) Shakespeare PHILIP H. CHRISTENSEN

117 "Meet the Real Lena Horne": Representations of Lena Horne in Ebony Magazine, 1945-1949

MEGAN E. WILLIAMS

\section{REVIEW ESSAY}

131 David Foster Wallace JAMES ANNESLEY

\section{REVIEWS}

EXCLUSIVE ONLINE REVIEWS www.journals.cambridge.org/ams 